\title{
Gretchen Sankey
}

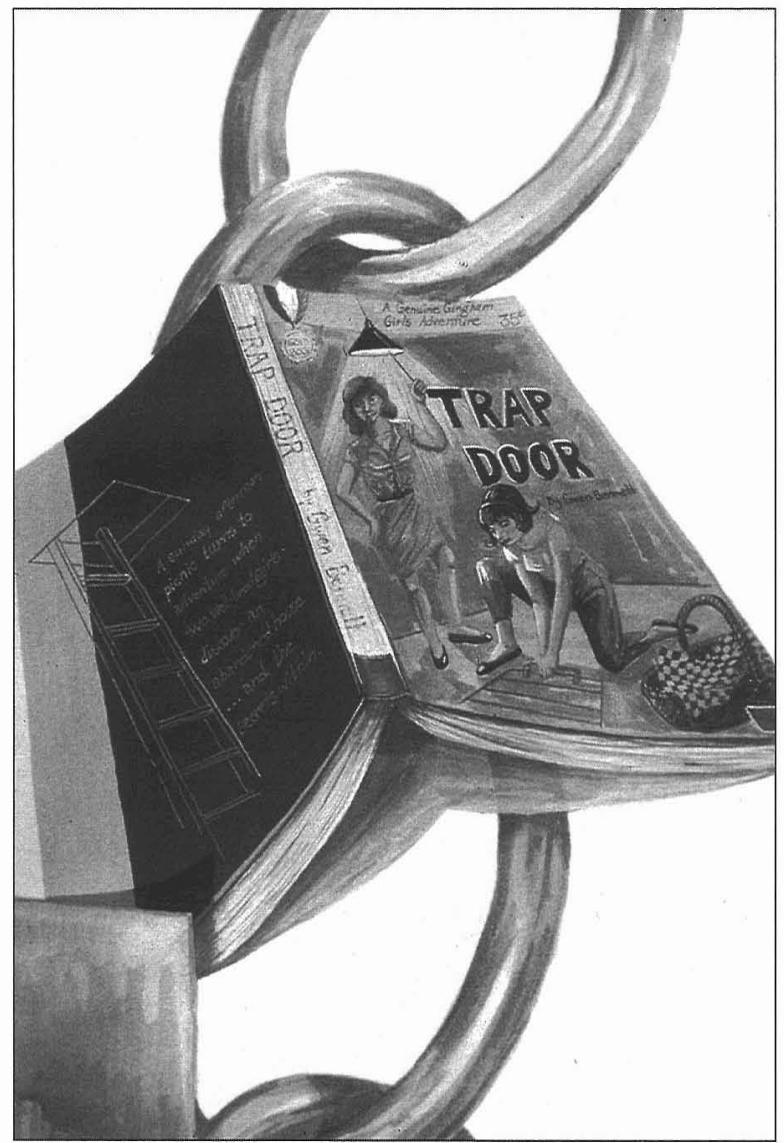

Morning After, 1998, ink and gouache on paper, $50 "$ × 35" (detail) 
$48 \cdot$ Tessera

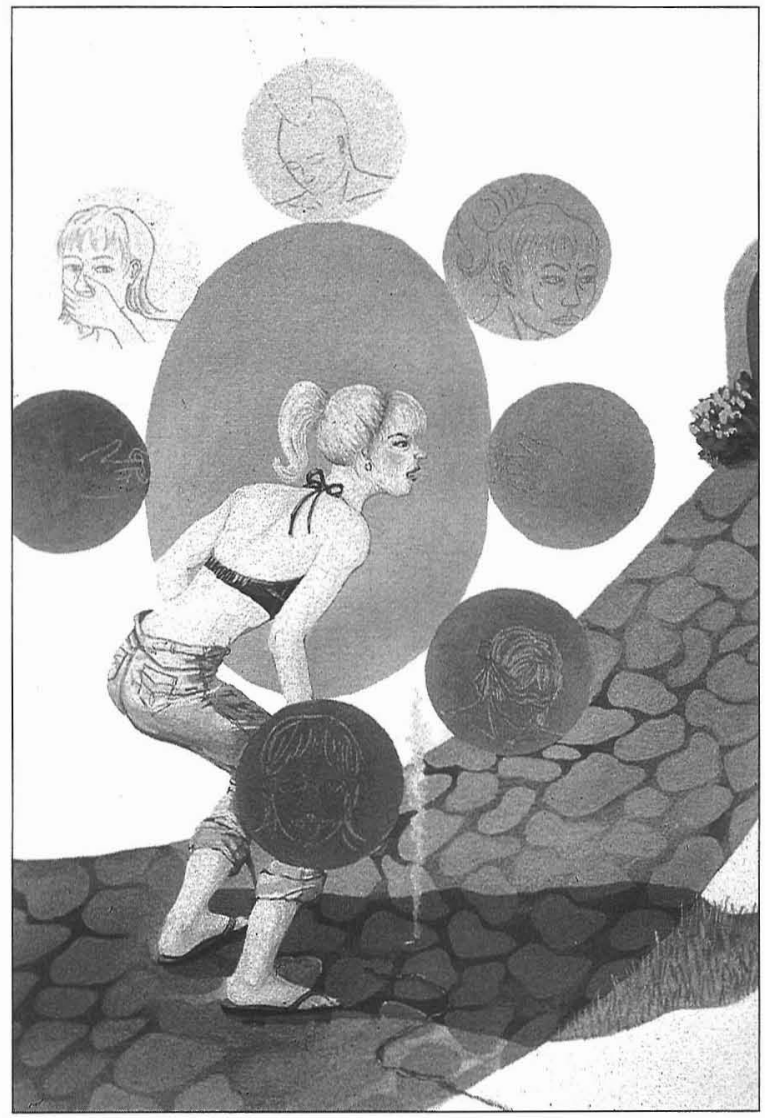

Wonder, 1998, ink, collage and gouache on paper, $50 "$ × 35" (detail) 